\title{
EL PERSPECTIVISMO LÍRICO DE RAMÓN PÉREZ DE AYALA
}

\author{
José Ramón GONZÁLEZ
}

Universidad de Valladolid

\section{RESUMEN}

El trabajo analiza la contribución de Ramón Pérez de Ayala a la renovación narrativa en la España del primer tercio del siglo XX. En sintonía con los grandes novelistas europeos del momento, el autor asturiano ensayó un tipo de novela lírica en la que la mirada interiorizada se fragmenta en multitud de perspectivas que aspiran a ofrecer una visión más compleja y rica de la realidad imaginada. La fusión de lirismo y perspectivismo, que aquí se denomina "perspectivismo lírico», constituye una de las grandes aportaciones de Pérez de Ayala al lenguaje narrativo de su época.

Palabras clave: Pérez de Ayala, novela modernista, novela lírica, perspectivismo, polifonía, metáfora.

\section{ABSTRACT}

The paper aims at describing Pérez de Ayala's contribution to the New Spanish Narrative at the beginning of the Twentieth Century. In line with the great European novelists of the moment, the Asturian author created a type of lyrical novel in which the interiorized glance fragments itself in multiple perspectives that aspire to offer a complex and rich vision of the imagined reality. This fusion of lyricism and perspectivism, that I denominate «lyrical perspectivism» here, constitutes one of the great contributions of Perez de Ayala to the narrative language of its time.

Key words: Pérez de Ayala, Modernist Novel, Lyrical Novel, Perspectivism, Poliphony, Metaphor. 
Como ha recordado recientemente Carlos Longhurst, los críticos y reseñistas de principios del siglo XX se vieron forzados a acuñar un buen número de nuevas etiquetas para referirse a la producción narrativa de los jóvenes escritores modernistas que iniciaban su andadura con la nueva centuria. Y lo mismo sucederá unos años más tarde con las obras de las sucesivas promociones que se darán a conocer como novelistas a lo largo de la primera, la segunda y la tercera década del siglo. Las pautas establecidas por los grandes narradores decimonónicos habían entrado en crisis y, de repente, ya no bastaba con hablar simple y llanamente de «novela»: se había roto un consenso tácito vigente durante más de treinta años y se hacía imprescindible recurrir a expresiones más matizadas y precisas que exigían una adjetivación definitoria:

En vez de hablar simple y llanamente de novelas, los comentaristas literarios se vieron paulatinamente en la necesidad de calificar el tipo de novelas de las que hablaban, acuñando etiquetas tales como novela filosófica, intelectual, psicológica, lírica, mitológica, formalista, deshumanizada, auto reflexiva, novela de artista e, incluso, anti-novela. (Longhurst: 31) [la traducción es mía]

La proliferación terminológica que conocen estos años y que se prolonga hasta la actualidad no es un mero capricho crítico -resultado de una especie de vértigo nominador-, sino la repuesta a una profunda transformación del género que abandona con rapidez los supuestos del realismo y del naturalismo, adentrándose por territorios apenas explorados. Al igual que sucede con la poesía, la novela se renueva radicalmente durante estos años en un afán de expresar ajustadamente la experiencia de una realidad expandida. Los viejos modos ya no sirven y los escritores recurrirán a estrategias alternativas que suponen la creación de un nuevo lenguaje poético y narrativo. Es como si -parafraseando a Sklovski- el prolongado predominio del realismo hubiese acabado por devorar la realidad que el movimiento pretendía reflejar de forma minuciosa y objetiva, y los lectores, víctimas de una percepción automatizada y anclada en la rutina, necesitasen el aliciente de una palabra distinta que les mostrase el mundo bajo una nueva luz y desde una perspectiva inédita. Y para lograr este objetivo, la novela modernista reajustará sus prioridades y modificará profundamente la arquitectura heredada de la novela clásica.

Nil Santiáñez Tió ha ahondado en la cuestión al describir con detalle las diferencias entre dos instancias, que él denomina «polos»-o «proyectos semióticos»- de la modernidad: el realista y el modernista.

Al romanticismo le sucede el realismo, y a éste el naturalismo, y a éste el simbolismo, y a éste las vanguardias, y a éstas la literatura comprometida. Y sin embargo, tal linealidad es equívoca, no sólo porque falsifica una característica definitoria de la modernidad literaria, esto es, la simultaneidad de corrientes, la manifestación multiforme del discurso literario; también lo es porque la 
diversificación de estilos y corrientes se organiza en torno a una estructura fundamental, o espectro de posibilidades, dentro del cual se enmarcan las obras en prosa de la modernidad. Este espectro tiene dos polos, o proyectos semióticos ideales, teóricos. Por un lado, el realista: lenguaje representativo, tendencia a la transparencia del código lingüístico, estructura metonímica, unidad del sujeto, organización temporal, relación del sujeto con su contexto biográfico y social, predominio de la historia sobre el discurso, predilección por lo unitario y coherente, tendencia a las visiones globales, subordinación al principio de contradicción. Por otro, el modernista: lenguaje experimental y dislocado, espesor del código lingüístico, estructura metafórica, disolución de la identidad personal, organización espacial, predominio del discurso sobre la historia, tendencia a la parodia y a la metaliteratura, simbolismo, polisemia del signo lingüístico, alejamiento de la función comunicativa, renuncia a las visiones globales, duda epistemológica. (Santiáñez: 74-75)

Y más adelante añade todavía en relación con el polo modernista: « [. . .] escepticismo religioso, especulación filosófica, ironía, alejamiento de las visiones globales, perspectivismo, relativismo, incertidumbre [. . .], narradores no fiables, interiorismo, mezcla de géneros, exigencia de un papel activo del lector» (Santiáñez: 132). Sin entrar a valorar en detalle las tesis generales del libro de Santiáñez, para quien ambos polos están activos a lo largo de un amplísimo arco temporal que supera con mucho la época finisecular de transición y ensayo que me interesa analizar, creo que proporciona una caracterización razonable y de gran utilidad de la novela modernista, y que logra resumir de forma sintética y ajustada las líneas de innovación narrativa y los rasgos propios de lo que fue percibido en su momento como un nuevo lenguaje artístico. Así pues, son muchas las modificaciones que sufre la novela en el fin de siglo y el desplazamiento modernista actúa simultáneamente sobre diferentes ejes -temáticos, enunciativos, estructurales o formales-, cuya precisa combinación determinará el alcance de la novedad en cada caso concreto.

Y a este mismo proceso se ha referido David Lodge, aunque en términos quizá un poco más limitados:

Lo que aparentemente sucede, primero en Francia y luego en Inglaterra, en la obra de James, Conrad, Joyce, y a su manera un tanto idiosincrásica, en Lawrence, es que el esfuerzo por apresar la realidad en la ficción narrativa, aplicado con cierto grado de intensidad, traslada al escritor al otro lado del «realismo». La prosa del escritor, por muy banal o sórdida que sea la experiencia que se supone que traslada, está tan trabajada y tan cuidada que deja de ser transparente y llama la atención sobre sí misma, merced a los brillantes reflejos oblicuos de su superficie. Así, al perseguir la realidad lejos del mundo diurno del sentido común empírico, profundizando en la conciencia -o subconciencia- individual y finalmente en el inconsciente colectivo, y al rechazar las estructuras narrativas gobernadas por la sucesión y la lógica 
de causa y efecto -que traicionan la naturaleza esencialmente caótica y problemática de la experiencia subjetiva- el novelista recurre cada vez con más intensidad a los mecanismos y estrategias literarias propias de la poesía y, más específicamente, de la poesía simbolista, alejándose de las que correspondían a la prosa: alusiones a modelos literarios y arquetipos míticos, por ejemplo, y la repetición de imágenes, símbolos y otros motivos -lo que E. M. Forster describió, en un nuevo gesto hacia el lenguaje de la música, como el «ritmo» de la novela. (Lodge: 6) [la traducción es mía]

Si me interesa la descripción de David Lodge, que cabría holgadamente en la detallada caracterización de Santiáñez Tió - de hecho, podemos considerarla implícita en ella-, es porque el teórico británico insiste, sin embargo, y de manera abierta, en un aspecto concreto que conviene subrayar en el contexto de mi argumentación. La novela modernista se aproxima, en su opinión, a la poesía y asimila los «mecanismos» y «estrategias» de composición propios del poema, ajustando a su manera y en su beneficio los recursos del lenguaje poético e invirtiendo las prioridades dominantes en la novela del realismo y del naturalismo. Lodge no llega a hablar abiertamente de «lirismo» o de «novela lírica», pero está claro que apunta hacia una hibridación genérica que se convertirá en uno de los más fértiles descubrimientos de la novela moderna. Poesía y novela ya no se concebirán como términos excluyentes, sino como fórmulas de escritura capaces de fundirse y potenciarse mutuamente. Por eso, a partir de ese momento lo poético y lo lírico definirán nuevas posibilidades de existencia novelística y, aunque es cierto que la modernidad narrativa no se agota en ellas, ambas representan una de sus más destacadas vertientes.

Darío Villanueva y Ricardo Gullón, en trabajos ya clásicos sobre la novela lírica que tuvieron la indudable virtud de generalizar una denominación de amplia circulación en Europa y en Estados Unidos, identificaron precisamente la renovación modernista con el ascenso del signo lírico y con el triunfo de la subjetividad y la interiorización (tal y como, por otra parte y desde una perspectiva ligeramente distinta, había hecho Pedro Salinas muchos años antes). Así, por ejemplo, al referirse a las transformaciones de la novela en el tránsito del realismo al modernismo, señala Gullón:

Si no se discute el hecho del cambio, sí se vacila en el modo de caracterizarlo y de nombrarlo. La novela decimonónica, unas veces con más razón que otras fue calificada, en general, de realista (con su antecedente costumbrista y la variante naturalista, a partir de Zola). En el siglo actual los nombres de la novela fueron múltiples. Pensando únicamente en los textos de que me propongo tratar aquí encuentro un repertorio de denominaciones amplio y variado: subjetiva, psicológica, lírica, interiorizada, poética, poemática, fragmentada, espacial, nivolesca...Y la lista no es completa. (Gullón: 15) 
Y en cuanto a las características de esta nueva novela, añade a continuación lo siguiente:

Seguramente las características más destacadas de las obras acogidas bajo estas rúbricas son la interiorización, el uso de la corriente de conciencia y del monólogo interior, la coherencia del punto de vista, la simultaneidad narrativa, la ruptura de la linealidad temporal y la exigencia de un lector activo que se situará inicialmente en la perspectiva del narrador o en la del personaje y aceptando la información autorial en los términos en la que le va siendo facilitada, se moverá a partir de ella hacia una recreación libre, y no por ello infiel al texto. (Gullón: 15-16)

La constelación de rasgos definitorios destacados por el crítico es lo suficientemente amplia como para permitir que se acojan bajo la denominación de novela lírica -que funcionará a lo largo del libro como una etiqueta englobadora y omnicomprensiva- una amplia variedad de textos de diferente orientación, alcance y profundidad. Para Gullón, y ciñéndonos a la literatura escrita en castellano, lírica será la novela de Martí, y lírica la de Unamuno, la de Valle-Inclán, la de Azorín, la de Gabriel Miró, la de Benjamín Jarnés, la de José María Arguedas y la de Ana María Matute. Y lírica será, por supuesto, la novela de Ramón Pérez de Ayala: «Las novelas de Ramón Pérez de Ayala divergen de las de Azorín y Miró en estructura, composición, persistencia del carácter e ironía narrativa», señala Gullón, pero «coinciden en el impulso renovador registrado en estas páginas bajo la rúbrica 'novela lírica'»(Gullón: 89).

Creo que la apreciación resulta ajustada y apunta con precisión al esfuerzo innovador del escritor asturiano, que ensayó, desde sus inicios narrativos a principios del siglo $\mathrm{xx}$, un tipo de novela alejada del realismo dominante, capaz de transmitir una visión más compleja y rica de la experiencia subjetiva. Su exploración constante de nuevas fórmulas -que le convierte en un escritor plenamente modernista, en sintonía con otros muchos narradores europeos (y así ha sido estudiado en varios trabajos importantes)- desembocará incluso en la creación de un nuevo género, la «novela poemática», en el que se fusionan prosa y poesía y en la que el verso proporciona una perspectiva complementaria de la realidad narrada y apunta hacia el descubrimiento -mediante la intuición- del sentido profundo de la existencia individual. En el «Alegato pro domo mea» que precede a la recopilación de su obra poética publicado en 1942, el autor nos recuerda que todas sus novelas -breves y largas- habían incorporado poemas, y se apresura a justificar tal procedimiento:

Creo que la poesía es el punto de referencia y, como si dijéramos, el ámbito en profundidad de la prosa narrativa. Muchas y enfadosas descripciones naturalistas ganarían en precisión y expresividad si se las cristalizase en un conciso poema, inicial del capítulo [...] Sucede también que el personaje novelesco 
atraviesa a veces trances de compleja tensión o sutilidad psíquicas, los cuales son de por sí inefables, como las intuiciones de los místicos. El minucioso análisis psicológico (que ha tiempo estuvo de moda en la novela) no sirve sino para acarrear fatiga y confusión. Por parte del novelista, no hay sino apelar a la poesía. Cervantes y Goethe dotaron de estas válvulas poéticas a sus novelas. (Pérez de Ayala 1964-1969, vol. II: 78-79)

Este recurso, si bien está presente en todas sus obras, ocupa un lugar especialmente destacado en las novelas que él mismo denominó «poemáticas» y que han sido estudiadas con admirable precisión por Miguel Ángel Lozano Marco y por Ángeles Prado. Ellas materializan el afán renovador de Pérez de Ayala y la propia denominación elegida por el autor subraya abiertamente su aspiración de novedad. Darío Villanueva ha resumido recientemente la aportación que suponen, retomando algunas de las consideraciones avanzadas en su trabajo de 1984:

Ramón Pérez de Ayala, amén de teorizador de las relaciones entre poesía y novela, es el reinventor novecentista de una modalidad inconfundible a este respecto: la novela poemática, en la que la inserción de poemas contribuye a condensar el otrora fatigoso discurrir de la anécdota, e incluso llega a imponer a la prosa una voluntad de acendramiento que, de rechazo, aproxima las pautas de la escritura narrativa a las de la lírica. Al tiempo, este impulso lírico aconseja una rigurosa selección de la calidad de los materiales diegéticos, o sustancia narrada: la eliminación de los elementos demasiado humanos de la obra literaria en aras de una intensidad que Ortega y Gasset proponía a la literatura en general y al género novelesco en particular en los años veinte [...] (Villanueva 2009: 167-168)

No voy, sin embargo, a ocuparme de esta modalidad narrativa, y ello por dos razones. La primera, porque ya ha sido minuciosamente estudiada y valorada en el contexto inmediato de la producción del autor y en el más amplio de la novela española contemporánea. La segunda, porque me interesa destacar un rasgo al menos igual de persistente -si no más- que impregna el conjunto de la narrativa del escritor asturiano. Porque si lo poemático -entendido como la combinación de prosa y verso- está presente en muchas de sus novelas -conviene recordar que varios de sus relatos extensos se anunciaban también como poemáticos en los años veinte y treinta-, lo lírico es el signo que domina su escritura desde el inicio hasta el fin de su carrera como novelista. Y es, además, un rasgo que se vinculará en la práctica con una de las estrategias narrativas preferidas por el autor, hasta el punto de haberse convertido en una de sus señas de identidad: el perspectivismo. De la fusión de ambos -lirismo y perspectivismo (o polifonía, si preferimos una más ajustada caracterización)nace un nuevo tipo de novela en la que se cifran los mayores logros del es- 
critor asturiano y que constituye una expresión original y verdaderamente novedosa. Pero para poder explicarlo detalladamente, vayamos por partes.

Recién publicada La pata de la raposa, la tercera de las novelas que componen la tetralogía autobiográfica protagonizada por Alberto Díaz de Guzmán, alter ego del propio Pérez de Ayala (aunque se trate más bien de una autobiografía generacional, como ha señalado perspicazmente Dolores Albiac), Valle-Inclán le escribe para transmitirle su opinión sobre la obra. Y lo hace en los siguientes términos (merece la pena citar por extenso la carta de Valle):

Querido Ayala: He recibido y leído La pata de la raposa. Me parece de sus tres novelas, la mejor. Tiene cierto aire de novela rusa, y ya sabe usted que para mí es el mayor mérito y el mayor elogio que puede hacerse de una novela. No me tome a mala parte, digo francamente mi parecer. No lo hago con nadie, pero como esta Pata de la raposa es una gran novela, llena toda de un fondo muy personal, yo creo hallar en ella un defecto de técnica, que, sin desagradarme, me sugiere otra manera de componer la novela. Voy a explicarme. En todos los capítulos está presente la acción y el pensamiento del protagonista. Es el centro de la acción siempre, todo lo llena, y, sin saber por qué, a mí como lector me comunica la impresión de que él mismo es quien escribe la novela. Es una impresión terca, que se impone irracionalmente, a pesar de la forma de narración impersonal en que está escrita la novela. Y ahora el defecto de técnica que yo creo advertir, sin estar muy seguro de no equivocarme. Pues esta impresión existe, creo que la novela hubiera ganado de estar escrita en forma de memorias.

Y aun añade:

¿Sabe usted, querido Ayala, una de las cosas que más contribuyen a que la novela parezca escrita por Alberto? La descripción y manera de tratar la figura de Fina. Parece pintada por su novio, no por un novelista. Hay una ternura íntima y contenida en todos estos episodios de Fina y Alberto, algo que se aproxima a la poesía lírica y amatoria, siempre autopersonal. (Pérez de Ayala 1970: 323)

En su afán de exponer con sinceridad lo que considera un defecto de técnica, Valle-Inclán desvela una de las características más llamativas de la novela de 1912 y de las restantes novelas de la tetralogía. El foco de percepción de la realidad narrada es casi siempre el protagonista, Alberto Díaz de Guzmán. El lector accede a la realidad imaginada por el autor a través del filtro de una conciencia y el mundo de los objetos y de las personas le llega tras haber pasado por el tamiz de una sensibilidad y una inteligencia -la del protagonista- que lucha por comprender el sentido de la existencia. Acierta pues Valle-Inclán, porque aunque la novela está escrita en tercera persona y la voz dominante es la de un narrador omnisciente, nos encontramos en realidad ante una omnisciencia selectiva y ante una falsa tercera persona. Lo es en cuanto a la voz, 
pero la focalización es muy frecuentemente interna y nos ofrece el mundo desde la intimidad del personaje. Y esto hasta el punto de que «el momento de percepción se constituye en el centro de la acción»-rasgo característico de la novela lírica, en palabras de Gullón, de las que me sirvo por su adecuación al caso particular- y el lector queda frente a frente «con el personaje o, dicho más precisamente, con los movimientos mentales del personaje» (Gullón: 19). Es decir, que el lector accede libremente a la conciencia del personaje principal y desde ese mirador atisba momentáneamente la existencia. Lo que pasa, lo que acontece, esto es, lo exterior, carece de importancia porque lo que interesa es el movimiento interior de la conciencia y sus reacciones. Afirma Gullón, refiriéndose a la novela lírica:

La intimidad del personaje y sus reacciones son exploradas minuciosamente, atendiendo a la impresión causada más que la acción causante, subordinada y como diluida en la impresión. Ejemplos tan disímiles como Peñas arriba, de José María Pereda, y To the Lighthouse, de Virginia Woolf, coinciden en echar atrás el incidente proyectando el foco de atención sobre la conciencia contemplativa y sobre su reflexión, acogido el sustantivo en sus dos acepciones: reflejo y meditación de lo contemplado. La complacencia en la presentación de estados de ánimo y en la descripción del paisaje, propone lo contemplado como equivalencia del contemplador y la referencia como expresión de la intimidad. (Gullón: 26)

Lo lírico nos transporta, por lo tanto, al instante de percepción y nos revela la intimidad en su dimensión actuante. Nos sitúa, como si dijéramos, en el centro de los procesos interiores del personaje y la realidad se nos hace presente en simultaneidad con el instante de aprehensión por parte del protagonista. Y para lograrlo el autor recurre a las imágenes y al empleo de un lenguaje que nos remite a una instancia de enunciación interna, que es el eje del relato y el lugar privilegiado de una intimidad en movimiento. Y esto es precisamente lo que Valle descubre en la obra de Pérez de Ayala.

Las diferencias entre esta novela lírica y las variantes del relato tradicional son más que notorias y no conviene confundir los términos. En la novela decimonónica abundan las descripciones psicológicas -más o menos profundas- que desvelan el mundo interior de los personajes y el narrador describe muy frecuentemente los pensamientos, las ilusiones, los deseos, los sueños, los temores o las frustraciones de los protagonistas, pero lo hace convirtiendo inevitablemente en objeto a sus criaturas, cosificándolas y transformándolas en materia inerte. Es como si las sometiera a una autopsia y luego nos ofreciera, exangües sobre la mesa, las vísceras espirituales que su escalpelo ha diseccionado. Vemos lo pensado, lo deseado, lo anhelado, lo temido, pero se nos escamotea el pensar, el temer, el desear y el anhelar, que son los verdaderos 
procesos vitales. De ahí que psicologismo y lirismo sean aproximaciones excluyentes. Una implica un dinamismo que va de lo exterior a lo interior y lo inmoviliza, lo congela; la otra, de lo interior a lo exterior. O, mejor aun, lo lírico se instala en el tránsito, en el flujo permanente, en el vaivén que va de uno a otro y que es una suma de instantes.

Inmediatamente retomaré algunas de estas cuestiones acompañado del espíritu protector de Ortega y Gasset, pero, de momento y para no alejarme demasiado del objeto de estudio, transitando como espíritu errabundo por las regiones de la abstracción, regreso a las novelas de Pérez de Ayala. Valle-Inclán comentaba en su carta que uno de los detalles que más contribuía al espejismo de la autoría de Alberto era la descripción de Fina. El tratamiento de su figura y la manera de pintarla con palabras revelaba una ternura íntima y contenida que aproximaba el texto a los territorios de lo lírico. Y eso es cierto, porque las palabras y las imágenes utilizadas por el narrador son aparentemente suyas, pero en la práctica remiten a un lugar que sólo podemos concebir como la conciencia de Alberto. No son una descripción externa y distanciada, porque en ellas se funde la intimidad del observador y la visión del objeto amado, hasta el punto de que Fina es sólo una construcción sentimental que perfila a contraluz la interioridad del personaje protagonista.

Para entender por qué sucede esto, es preciso dar un pequeño rodeo digresivo (este podría ser también un viaje entretenido, en el sentido en el que Ayala utilizaba el término). Se trata de una breve incursión en el pensamiento de Ortega, que supo identificar y reconocer el impulso lírico como signo de modernidad estética. Y para ello es preciso detenerse por unos momentos en un texto bien conocido, aunque sin duda no tan famoso como sus grandes trabajos de los años veinte. Me refiero al «Ensayo de estética a manera de prólogo», que figuraba como pórtico en el libro El pasajero de José Moreno Villa, publicado en 1914.

En los apartados II, III y IV del mencionado ensayo, el filósofo contrapone, primeramente, la diferencia que media entre la realidad externa y el yo, o mejor aún, entre las cosas como objeto de conciencia y la vivencia de esas mismas cosas (no olvidemos que no estaban aun muy lejanas las enseñanzas de Brentano y Husserl, e incluso del noekantiano Cohen, y que Ortega iba ya elaborando su particular concepción de la realidad). Las cosas, eso que llamamos las cosas, son imágenes que nuestra conciencia proyecta congeladas sobre un escenario ideal, mientras que el yo es el punto siempre inasible desde el que la voluntad pone en marcha el proyector perspectivístico. Es decir, el yo, en cuanto lugar desde el que se enfoca la realidad, en cuanto ámbito de conciencia, que es actividad, movimiento siempre elusivo -y que es 
el territorio propio de lo lírico, no lo olvidemos-, no puede ser aprehendido intelectualmente por el propio sujeto, salvo que lo fije como objeto de conocimiento en imagen, en concepto, en idea; pero entonces ese yo no es el yo que está viviendo esa experiencia de conocimiento, sino algo diferente que de nuevo se nos escapa (el yo activo se ha trasladado a un nuevo espacio desde el que mira un yo fantasmagórico o espectral). Afirma Ortega:

[N]o podemos hacer objeto de nuestra comprensión, no puede existir para nosotros nada si no se convierte en imagen, en concepto, en idea - es decir, si no deja de ser lo que es, para transformarse en una sombra o esquema de sí mismo. Sólo con una cosa tenemos una relación íntima: esta cosa es nuestro individuo, nuestra vida, pero esta intimidad nuestra al convertirse en imagen deja de ser intimidad [deja de ser «vivencia», podríamos añadir]. (Ortega: 254)

$\mathrm{Y}$, un poco más adelante, «la verdadera intimidad que es algo en cuanto ejecutándose, está a igual distancia de la imagen de lo externo como de lo interno» (Ortega: 254). La intimidad sólo puede conceptualizarse entonces como el punto ciego que hace posible nuestra visión. La vivencia íntima del mirar no puede al mismo tiempo ser mirada en lo que tiene de tal vivencia. Lo paradójico del caso es que, como añade Ortega, «[l]a intimidad no puede ser objeto nuestro ni en la ciencia, ni en el pensar práctico, ni en el representar imaginativo; sin embargo, es el verdadero ser de cada cosa, lo único suficiente y de quien la contemplación nos satisfaría con plenitud» (Ortega: 254). Con la expresión de esta ansiada plenitud, que no sería otra cosa que el triunfo de apresar la vida en cuanto vividura, permítaseme la expresión, hemos llegado a un aparente punto muerto, porque si esto es realmente como lo plantea el filósofo ¿cómo representar entonces artísticamente -sea cual sea el medio empleado- lo que, por principio, no puede ser objeto de representación? Y es que para Ortega está claro que el ser de cada cosa no admite una simple y directa transcripción lingüística. «La narración -y repito sus palabras- hace de todo un fantasma de sí mismo, lo aleja, lo traspone más allá del horizonte de la actualidad. Lo narrado es un fue, y el fue es la forma esquemática que deja en el presente lo que está ausente, el ser de lo que ya no es -la camisa que la sierpe abandona» (Ortega: 256) ¿Cómo entonces?, podemos preguntarnos. Es preciso imaginar nuevas vías: «un idioma o un sistema de signos expresivos de quien la función no consistiera en narrarnos las cosas [o en describirlas, podríamos añadir], sino en presentárnolas como ejecutándose» (Ortega: 256). Pues bien, «[t]al idioma es el arte: esto hace el arte», afirma rotundo Ortega. «El objeto estético es una intimidad en cuanto tal -es todo en cuanto yo» (Ortega: 256). Esa es finalmente la fórmula a la que llega, y que no abandonará, sino que matizará, en los años siguientes (el arte ha de presentar 
la realidad ejecutiva de las cosas), aunque, eso sí, Ortega se cuida mucho de sortear un último escollo en su camino: el que representa el concepto de Einfülung o «empatía» acuñado por los filósofos alemanes Teodor Lipps y Nelson Worringer (creadores de una estética de base psicológica y con los que Ortega -y Pérez de Ayala- está en deuda), y que llevaba aparejada la idea de proyección sentimental: en la experiencia estética el sujeto se proyecta sobre el objeto, viviendo en su plenitud la nueva realidad, aunque desde un marco diferente. Para Ortega esto es inaceptable en tanto y en cuanto la experiencia estética no anula la conciencia de la propia individualidad. El hombre sabe que está viviendo un simulacro, una ficción. Por eso afirma el filósofo:

No digo -cuidado- que la obra de arte nos descubra el secreto de la vida y del ser; sí digo que la obra de arte nos agrada, con ese peculiar goce que llamamos estético, por parecernos que nos hace patente la intimidad de las cosas, su realidad ejecutiva -frente a quien las otras noticias de la ciencia parecen meros esquemas, remotas alusiones, sombras y símbolos. (Ortega: 256)

Ortega apunta a lo lírico como objeto estético por antonomasia, hasta el punto de que experiencia estética y experiencia lírica funcionan casi como expresiones sinónimas. Pero no basta declarar que el arte es el lenguaje que permite aprehender la intimidad en cuanto tal, porque permanece abierta la cuestión de los medios y los recursos que se deben emplear para lograrlo. Y aquí el filósofo va a apuntar su conocida teoría de la metáfora.

Como supo ver perspicazmente, la metáfora (o la comparación) es una realidad verbal constituida por tres elementos: A y B, los elementos puestos en relación (o vehículo y tenor, si preferimos una terminología diferente) y el «[1]ugar sentimental o la forma yo de ambas» (Ortega, pág. 261) -el espacio de intimidad, el crisol en el que ambos objetos, A y B, se funden. Por eso, la metáfora vendrá a expresar, no la conciencia inmovilizada, cosificada, sino la conciencia en su proceso, ejecutándose:

[...] la función expresiva del idioma se limita a expresar con unas imágenes (las sonoras o visuales de las palabras), otras imágenes -las cosas, las personas, las situaciones, los sentimientos-, y el arte, en cambio, usa de los sentimientos ejecutivos [plasmados en la metáfora, conviene precisar] como medios de expresión y merced a ello da a lo expresado el carácter de estarse ejecutando. Diríamos que si el idioma nos habla de las cosas, alude a ellas simplemente, el arte las efectúa. (Ortega: 262)

La confluencia textual de dos elementos dispares que suponemos con una base común, nos proyecta necesariamente fuera del texto, hacia el espacio sentimental en donde opera tal identificación. Por eso la novela lírica recurrirá frecuentemente a las imágenes para sumergirnos en la conciencia actuante. Señala así Gullón, en sintonía con Ortega: 
Las imágenes en cuanto modalidades peculiares de la percepción, sirven en el texto una función impregnante de lo experimentado por la figura-narrador o personaje. La sensación inicial se traduce en asociaciones verbales adecuadas para hacerlas sentir según fueron: el receptor descifra la confidencia como «mensaje», y todo lo demás como medio de intensificar y precipitar su sentido. (Gullón: 26)

Y Darío Villanueva tras recordar, por su parte, que «la metáfora es una forma paladina de subjetivización de la realidad» (Villanueva 2009: 166), señala, en sintonía con lo apuntado por Ortega, que en la novela lírica:

[...] el yo genera una secuencia de imágenes transformadoras de la realidad, o de epifanías reveladoras de ella, al tiempo que se consolida y toma conciencia de sí mismo como -valga la redundancia y el neologismo- mismidad. Como el self de los jungianos. El protagonista es creador del universo narrado en el que aparece inserto; el sujeto y el objeto se identifican, y el yo narrativo desempeña la misma función que el yo lírico de la poesía en verso. (Villanueva 2009: 159)

Hasta aquí Ortega y su análisis de la metáfora y la comparación, que son instrumentos líricos por excelencia y que al mismo tiempo se identifican con el objeto propiamente estético: «Este objeto que se transparenta a sí mismo, el objeto estético encuentra su forma elemental en la metáfora. Yo diría que objeto estético y objeto metafórico son una misma cosa, o bien, que la metáfora es el objeto estético elemental, la célula bella» (Ortega: 257).

Retornando ahora a las novelas de Ayala, podemos constatar pues que Valle-Inclán, finísimo lector, acertó plenamente en su comentario. La descripción de Fina nos traslada al mundo interior de Alberto, que es quien mira con ternura «íntima y contenida», y no a la conciencia del narrador, aunque sea éste quien hable en el texto (podríamos decir, en todo caso, que ambos se identifican por momentos). Los términos elegidos para describir a la protagonista no son términos neutros, distanciados, sino vocablos connotados que arrastran un poso de subjetividad y que nos trasladan directamente al lugar interior desde el que se observa el mundo. Y esta perspectiva interior (o interiorizada) es la que predominará a lo largo de las cuatro primeras novelas, que, ahora sí, podemos considerar cumplidos ejemplos de novela lírica.

Pero hay algo más -y apunto al segundo de los elementos que incorpora el título de mi trabajo-: la perspectiva asumida no es única, ni se mantiene estable a lo largo de cada una de las novelas. Ayala nos sitúa con frecuencia en la conciencia de Alberto, pero también en la de otros muchos personajes, a veces incluso secundarios o episódicos, de tal manera que, en puridad, tendríamos que plantearnos la existencia de un lirismo polifónico (o de algo, que a falta de mejor expresión podemos llamar así por el momento). Y esta técnica 
parece haber sido cultivada conscientemente por el autor desde sus primeras novelas. $\mathrm{O}$ al menos eso es lo que se desprende de los comentarios que se incluyen en el prólogo de la edición argentina de sus Troteras y danzaderas publicada en Buenos Aires en 1942. En él, Pérez de Ayala subraya la unidad de las cuatro novelas y, al mismo tiempo, su relativa independencia (pueden ser leídas por separado, como piezas de un retablo). Uno de los elementos de unión lo constituyen precisamente los personajes episódicos, que «trashuman de una a otra», adquiriendo diferente peso y grados de protagonismo según lo aconsejan las circunstancias y según las necesidades del relato. Al hilo de esta descripción de los personajes episódicos, el autor desliza un comentario revelador:

Una novela se desarrolla siempre en 'presente' (aunque la narración esté en pretérito. La narración en pretérito es un presente panorámico, así como en la narración en presente el tiempo se va desglosando y pereciendo en gotas de agua o tic-tac de reloj). Quiero decir que una novela se compone de las reacciones de conciencia de cada personaje frente al presente vital. Así, cada uno de aquellos personajes episódicos representan (o pretenden representar) actitudes fundamentales de la conciencia individual ante la vida, en ciertos momentos, o presentes, que para uno de ellos, y no para los otros, les provocan o estimulan una reacción vital, defensiva u ofensiva (Pérez de Ayala 1942: 5).

Resulta evidente que al situarse en determinados «momentos»-concebidos como «presentes» intransferibles que provocan o estimulan una reacción vital- el autor está permitiendo que el lector viva ese instante desde la perspectiva de cada uno de los personajes. Y el resultado es una visión compleja del universo narrado, que alcanza renovada profundidad. El concepto de perspectivismo, tan hábilmente planteado por Baquero Goyanes o por Frances Weber para analizar la obra de Pérez Ayala, debe expandirse para incluir el perspectivismo lírico, que permite revivir en la lectura los acontecimientos narrados desde lugares de conciencia diferentes, pero, al mismo tiempo, complementarios. Y todo ello en la instantaneidad de su alternarse. Tal procedimiento coral supone un enriquecimiento de la novela lírica, que «suele recurrir a modelos propios de la narrativa autobiográfica» (Villanueva 2009: 159), pero que en este caso se abre a una pluralidad de enfoques que exceden los límites de lo que solemos denominar «literatura del yo». Lo que el autor nos ofrece es una sucesión de posiciones líricas, desplazando el pivote en el que se apoya la realidad narrada y ensanchando el enfoque narrativo de la novela.

Años más tarde, cuando el autor inicie la segunda etapa de su carrera como novelista (las grandes novelas de la segunda época) retomará la misma técnica, en la que profundizará de manera consciente e intencionada, hasta 
el punto de que se convertirá en rasgo caracterizador de su escritura. Y como ocurre con otras muchas cuestiones de estética, el escritor aprovechará las digresiones tan comunes en sus textos para exponer sus concepciones narrativas y la poética que guía su novelar. El capítulo segundo de Berlamino y Apolonio resulta a este respecto revelador. Recordemos que, en uno de sus habituales pronunciamientos irónicos, el mencionado capítulo se presenta como prescindible o accesorio: «(El lector impaciente de acontecimientos recorra con mirada ligera este capítulo que no es sino el escenario donde se va a desarrollar la acción)» (Pérez de Ayala 1978: 90). Y sin embargo en él se exponen cuestiones que atañen muy directamente a su técnica como narrador. Enfrentado a la necesidad de describir la Rúa Ruera que es, en efecto, uno de los escenarios principales de la novela, al narrador se le hace presente el espíritu de don Amaranto del Fraile un antiguo mentor a quien conoció como huésped de pensión y con quien compartió largas conversaciones filosóficas (es un filósofo de casa de huéspedes y a él estará dedicado el prólogo de la novela). El espectro de don Amaranto reflexiona sobre la diferencia entre la mirada del pintor y la del escritor y sobre la necesidad de dotar a la escritura de profundidad. «El novelista, en cuanto hombre, ve las cosa estereoscópicamente, en profundidad; pero, en cuanto artista, está desprovisto de medios con que reproducir su visión. No puede pintar: únicamente puede describir, enumerar. La misión de ver con mayor profundidad, delicadeza y emoción y enseñar a los otros a ver de la propia suerte, le toca al pintor» (Pérez de Ayala 1978: 92). Y para lograrlo, y después de un pequeño rodeo, no encuentra otro método que el de optar por lo que denominará una visión «diafenomenal». Fijémonos en la respuesta a la pregunta de cómo debe describir el narrador la Rúa Ruera:

No describiéndola. Busca la visión diafenomenal. Inhíbete en tu persona de novelista. Haz que otras dos personas la vean al propio tiempo, desde ángulos laterales contrapuestos. Recuerda si en alguna ocasión te aconteció ser testigo presencial de cómo ese mismo objeto, la Rúa Ruera, suscitó duplicidad de imágenes e impresiones en dos observadores de genio contradictorio; y tú ahora amalgama aquellas imágenes e impresiones. (Pérez de Ayala 1978: 93)

El consejo no puede ser más claro. Se trataría de trasladar al lector imágenes o impresiones dobles o múltiples que permitirían alcanzar el efecto de profundidad buscado. Pero, ¿de qué estamos hablando cuando hablamos de impresiones o imágenes de dos o más observadores? ¿No significa esto que el narrador nos sitúa en una doble perspectiva que debe entenderse como una sucesión de instantes vividos desde diferentes conciencias? El repaso de los textos de su segunda época narrativa revela precisamente el lugar central que 
este mecanismo narrativo va a ocupar en su novelística, hasta el punto de que fue percibido como uno de los rasgos más innovadores de su escritura.

En Belarmino y Apolonio aprehendemos la realidad a través de la mirada interior de los dos protagonistas principales, pero también a través de Angustias y Pedrito. E incluso, en una ampliación de focos, a través del narrador/ autor y de El Estudiantón. Y algo parecido, pero aun más evidente, sucederá en Tigre Juan y El curandero de su honra, en donde esa pluralidad se expresa tipográficamente mediante el desdoblamiento en columnas que sugiere no sólo la simultaneidad de acciones, sino también, y por la particular configuración narrativa, de perspectivas y miradas.

En definitiva, Ramón Pérez de Ayala cultivó un tipo de novela rupturista, en sintonía con los más importantes renovadores de la novela española y europea de principios del siglo $\mathrm{xx}$, y contribuyó notablemente a la creación de un nuevo lenguaje narrativo que supo enriquecer mediante la incorporación de un perspectivismo lírico en el que las voces y las miradas se entrecruzan para ofrecernos una visión compleja y profunda de la realidad imaginada.

\section{BIBLIOGRAFÍA}

AlBIAC, María Dolores. 1982. «Autobiografía personal y biografía generacional en la obra de Ramón Pérez de Ayala», en L’Autobiographie en Espagne. Actes du IIe Colloque Internacional de La Baume-les-Aix. Aix-en-Provence, Universite de Provence, págs. 181-201.

Baquero Goyanes, Mariano. 1963. Perspectivismo y contraste (de Cadalso a Pérez de Ayala). Madrid, Gredos.

COlETES, Agustín. 1987. La huella anglonorteamericana en la novela de Pérez de Ayala. Murcia, Universidad de Murcia / Universidad de Oviedo.

FreEdman, Ralph. 1972. La novela lírica. Hermann Hesse, André Gide y Virginia Woolf. Barcelona, Barral.

Gullón, Ricardo. 1984. La novela lírica. Madrid, Cátedra.

LODGE, David. 1986. Working with Structuralism. Essays and Reviews on Nineteenth and Twentieth-Century Literature. Londres, Ark Paperbacks.

LONGHURST, Carlos Alex. 2008. «The Early Twentieth-Century Novel», en Marta E. Altisent (ed.), A Companion to the Twentieth-Century Spanish Novel, Woodbridge, Tamesis, págs. 30-44.

LOZANO MARCO, Miguel Ángel. 1983. Del relato modernista a la novela poemática: la narrativa breve de Ramón Pérez de Ayala. Alicante, Universidad de Alicante.

MACKLIN, John. 1988. The Window and the Garden: The Modernist fictions of Ramón Pérez de Ayala. Boulder (Colorado), Society of Spanish and Spanish American Studies. 
ORTEGA y GASSET, José. [1914] 1989. «Ensayo de estética a manera de prólogo», en Obras Completas, VI. Madrid, Alianza.

PÉREZ DE Ayala, Ramón. 1942. Troteras y danzaderas. Buenos Aires, Losada.

- 1964-1969. Obras completas, IV vols. Madrid, Aguilar.

- 1970. La pata de la raposa. Barcelona, Labor.

- 1978. Belarmino y Apolonio. Madrid, Cátedra.

Prado, Ángeles. 1981. «Las novelas poemáticas de Ramón Pérez de Ayala». Cuadernos Hispanoamericanos 367-368, págs. 41-70.

- 1998. «Introducción», en Ramón Pérez de Ayala, El ombligo del mundo, Madrid, Cátedra.

SANTIÁÑEZ, Nil. 2002. Investigaciones literarias. Modernidad, historia de la literatura y modernismos. Barcelona, Crítica.

Villanueva, Darío. 1984. La novela lírica, I y II. Madrid, Taurus.

- 2009. «La novela lírica de Francisco Umbral», en Santos Sanz Villanueva (ed), Francisco Umbral y su tiempo, Valladolid, Ayuntamiento de Valladolid y Fundación Francisco Umbral, págs. 149-176.

Weber, Frances Wyers. 1966. The Literary Perspectivism of Ramón Pérez de Ayala. Chapel Hill, The University of Carolina Press.

Fecha de recepción: 26 de febrero de 2009.

Fecha de aprobación: 28 de marzo de 2009. 